\title{
STUDI EVALUASI PROFESIONALISME GURU PRAKARYA DAN KEWIRAUSAHAAN DITINJAU PERSEPSI SISWA XI MIA SMAN 4 SINGARAJA
}

\author{
G. N. Darma Suarya ${ }^{1}$, N. Santiyadnya ${ }^{2}$, I P. Suka Arsa ${ }^{3}$ \\ 1,2,3 Prodi Pendidikan Teknik Elektro, Universitas Pendidikan Ganesha, Singaraja \\ e-mail: darmasuarya@gmail.com, santiyadnya@undiksha.ac.id, suka.arsa@undiksha.ac.id
}

\begin{abstract}
Abstrak
Penelitian ini bertujuan mendeskripsikan tentang profesionalisme guru mata pelajaran prakarya dan kewirausahaan yang ditinjau dari persepsi siswa. Dimana profesionalisme tersebut dilihat dari empat standar kompetensi guru antara lain, kompetensi profesional, kompetensi pedagogik, kompetensi kepribadian, dan kompetensi sosial. Populasi dalam penelitian ini yaitu siswa kelas XI MIA SMA Negeri 4 Singaraja dengan melibatkan 70 responden. Teknik pengumpulan data yang digunakan antara lain, kuesioner, wawancara, observasi, dan studi dokumen. Metode penelitian yang digunakan, yaitu metode kualitatif deskriptif. Berdasarkan analisis data, didapatkan hasil antara lain 1) Profesionalisme guru mata pelajaran prakarya dan kewirausahaan yang ditinjau dari persepsi siswa masih kurang. Dilihat dari kompetensi yang memenuhi kriteria hanya tiga kompetensi dari empat kompetensi yang disyaratkan oleh PP No.74 Tahun 2008 dan Permendiknas No.16 Tahun 2007, yaitu kompetensi profesional, kompetensi kepribadian, dan kompetensi sosial. 2) Pada kompetensi pedagogik guru belum memenuhi semua kriteria yang disyaratkan, yaitu kriteria perancangan pembelajaran dan pelaksanaan pembelajaran yang mendidik dimana guru dalam pembelajaran tidak selalu sesuai atau tidak berpedoman pada RPP.
\end{abstract}

Kata Kunci: Evaluasi, Persepsi, Profesionalisme Guru, Kompetensi Guru

\begin{abstract}
This study aims to describe about the professionalism of the teacher of craft and entrepreneurship in terms of perceptions of students. Where professionalism is viewed from four teacher competency standards, among others, professional competence, pedagogical competence, personal competence and social competence. The population in this study is a class XI student of SMAN 4 Singaraja MIA involving 70 respondents. Data collection techniques used, among others, questionnaires, interviews, observation and documents. The method used, namely the descriptive qualitative method. Based on data analysis, showed among other things 1) Professionalism teacher of craft and entrepreneurship in terms of the perception of the students were still lacking. Judging from the competencies that meet the criteria of competence only three of the four competencies required by Regulation 74 of 2008 and Permendiknas 16, 2007, namely professional competence, personal competence and social competence. 2) In the pedagogical competence of teachers has not met all the required criteria, ie criteria for instructional design and implementation of educational learning where teacher learning is not always appropriate or not based on the RPP.
\end{abstract}

Keywords: Evaluation, Perception, Professional Teacher, Teacher Competence

\section{Pendahuluan}

Pendidikan merupakan faktor penting dalam meningkatkan kualitas sumber daya manusia. Pendidikan merupakan sarana utama dalam mengembangkan ilmu pengetahuan dan teknologi. Pendidikan dapat menciptakan sumber daya manusia yang mampu menjawab setiap tantangan dan hambatan dalam era globalisasi sekarang ini. Arti pendidikan menurut Undang-Undang Sistem Pendidikan Nasional adalah usaha sadar dan terencana untuk mewujudkan suasana belajar dan proses pembelajaran agar peserta didik secara aktif mengembangkan potensi dirinya untuk memiliki kekuatan spiritual keagamaan, pengendalian diri, kepribadian, kecerdasan, akhlak mulia, serta keterampilan yang diperlukan dirinya, masyarakat, bangsa dan negara.

Mutu pendidikan perlu diperhatikan untuk mencapai tujuan pendidikan, sedangkan mutu sendiri dapat dilihat dari keberhasilan yang diraih oleh seorang siswa selama mengikuti 
kegiatan belajar mengajar. Pendidikan dikatakan berhasil apabila didukung oleh guru yang profesional. Profesionalitas guru akan berpengaruh pada kualitas pendidikan. Pendidikan yang bermutu adalah pendidikan yang mampu mengelola peserta didiknya menjadi lulusan atau output yang berkualitas berkompeten (Aminatul Zahroh, 2015:22).

Profesionalisme adalah suatu keahlian yang dimiliki seseorang dalam suatu bidang tertentu dan telah dapat memberikan ilmu pengetahuan kepada masyarakat yang membutuhkan. Guru yang profesional adalah guru yang benar-benar ahli dalam bidangnya dan mampu melaksanakan tugasnya dengan baik sekaligus memiliki kompetensi dan komitmen yang tinggi dalam menjalankkan tugas dan tanggung jawabnya. Guru memiliki peran yang strategis dalam bidang pendidikan, bahkan sumber pendidikan lain yang memadai seringkali kurang berarti apabila tidak didukung oleh keberadaan guru yang berkualitas. Dengan kata lain, guru merupakan ujung tombak dalam upaya peningkatan kualitas layanan dan hasil pendidikan. Hal tersebut tak lepas juga dari mata pelajaran yang diampunya, dimana mata pelajaran prakarya dan kewirausahan yang diajarkan pada tingkat SMA oleh guru yang bersangkutan juga harus memiliki profesionalisme sebagai seorang guru. Profesionalisme tersebut tak lepas dari kaitannya dengan peserta didik, karena peserta didiklah yang paling sering berhubungan dengan guru, sehingga segala sikap, prilaku, kinerja, cara mengajar, kedisiplinan, pribadi, serta sosial peserta didiklah yang paling mengetahui dari guru tersebut.

Mengingat pentingnya peran guru dalam kemajuan pendidikan maka kinerja guru harus menjadi perhatian utama. Seorang guru harus memiliki kinerja yang bagus guna menciptakan kualitas pendidikan yang baik. Guru yang profesional harus memenuhi empat kompetensi yang telah disebutkan dalam UU RI Nomor 20 tentang Sistem Pendidikan Nasional Tahun 2003 dan Peraturan Pemerintah Nomor 19 Tahun 2005 tentang Standar Nasional Pendidikan. Keempat kompetensi tersebut adalah kompetensi pedagogik, kompetensi profesional, kompetensi pribadi dan kompetensi sosial.

SMA Negeri 4 Singaraja termasuk dalam pendidikan umum yang lebih dikenal Sekolah Menengah Atas (SMA). SMA Negeri 4 Singaraja temasuk sekolah yang favorit di Singaraja, dikarenakan prestasi yang diraih dari siswa-siswinya. Sehingga banyak siswa yang berasal dari luar Singaraja mengikuti pendidikan di sekolah ini. SMA Negeri 4 Singaraja menggunakan Kurikulum 2013, dimana dalam kurikulum ini terdapat mata pelajaran baru yaitu Prakarya dan Kewirausahaan. Dalam mata pelajaran ini lebih banyak menuntut skill dan keterampilan seseorang dalam berwirausaha.

Prakarya dan kewirausahaan merupakan sebuah mata pelajaran yang terdiri dari dua suku kata yaitu prakarya dan wirausaha. Prakarya merupakan hasil kerja berupa keterampilan, hastakarya, kerajinan yang penggunaan bahannya tersedia secara umum. Prakarya mempunyai peranan penting dalam pengembangan. Kreativitas menjadi sebuah inovasi baru. Kewirausahaan merupakan proses kemanusiaan yang berkaitan dengan adanya kreativitas serta inovasi dalam memahami suatu peluang, mengorganisasikan sumber-sumber serta mampu mengelola sehingga peluang tersebut dapat terealisasi dengan baik. Sehingga prakarya dan kewirausahaan dapat diartikan sebagai ilmu pengetahuan yang berbasis keterampilan, kerajinan dan hastakarya yang bersifat inovatif dan mampu menjadikan hasil karya tersebut menjadi sebuah peluang, mengorganisasikan dan mampu mengelola inovasi hasil karya dan keterampilan didalam berwirausaha.

Hasil pengamatan peneliti selama melaksanakan PPL-Real di SMA Negeri 4 Singaraja mendapatkan beberapa temuan-temuan di antaranya: banyak siswa yang kurang antusias mengikuti pembelajaran, minat siswa akan mata pelajaran prakarya dan kewirausahaan yang rendah dilihat dari beberapa siswa yang kurang aktif sewaktu kegiatan belajar mengajar yang diberikan oleh guru. Pada umumnya siswa yang memiliki persepsi positif terhadap metode mengajar guru akan merasa senang dalam mengikuti pelajaran sehingga siswa akan memperhatikan guru ketika menyampaikan materi pelajaran dan ikut serta aktif dalam kegiatan pembelajaran. Jika siswa memiliki persepsi negatif terhadap metode mengajar guru, maka siswa kurang memperhatikan materi yang diajarkan oleh guru dan sulit untuk memahami apa yang akan diajarkan oleh guru sehingga akan mempengaruhi prestasi belajar siswa yang rendah. 
Dari pemaparan diatas profesionalisme guru dapat dilihat dari berbagai aspek. Seperti sertifikasi guru, penilaian kinerja guru, kompetensi guru. Dalam kompetensi guru ada empat kompetensi yang harus dicapai oleh seorang guru yang profesional antara lain kompetensi profesional, kompetensi pedagogik, kompetensi kepribadian, kompetensi sosial. Guna mengetahui profesionalisme guru tersebut tentunya melalui evaluasi yang dilaksanakan terhadap siswa dan guru terkait.

Sesuai dengan permasalahan yang telah dibahas pada latar belakang diatas, maka Tujuan dari penelitian ini yaitu, mendeskripsikan tentang profesionalismeguru mata pelajaran prakarya dan kewirausahaan yang ditinjau dari persepsi siswa. Dimana profesionalisme tersebut dilihat dari empat standar kompetensi guru, yaitu: kompetensi profesional; kompetensi pedagogik; kompetensi kepribadian; kompetensi sosial.

Pupuh Fathurrohman (2011:75) mengemukakan untuk dapat menentukan tercapai tidaknya tujuan pembelajaran, perlu dilakukan usaha atau tindakan penilaian /evaluasi. Evaluasi adalah kegiatan yang terencana untuk mengetahui keadaan suatu objek dengan menggunakan instrumen dan membandingkan hasilnya dengan tolak ukur untuk memperoleh kesimpulan. Selanjutnya Nana Sudjana (dalam Pupuh Fathurrohman 2011:75) menjelaskan bahwa evaluasi pada dasarnya memberikan pertimbangan atau harga atau nilai berdasarkan kriteria tertentu.

Didalam Arikunto (2009: 40) terdapat 7 model evaluasi pendidikan antara lain FormatifSummatif Evaluation Model.Yaitu evaluasi formatif secara prinsip merupakan evaluasi yang dilaksanakan ketika program sedang berlangsung. Tujuan evaluasi ini adalah mengetahui seberapa jauh program yang dirancang dapat dilaksanakan dan dapat mengetahui hambatanhambatan didalam pelaksanaannya. Evaluasi sumatif dilaksanakan setelah program berakhir. Tujuan evaluasi sumatif ini adalah untuk mengukur ketercapaian program sebagai sarana yang berfungsi mengetahui hasil yang dicapai oleh objek penelitian.

Profesi merupakan suatu pekerjaan atau jabatan yang memerlukan suatu keahlian khusus dalam menjalankannya, sehingga seorang yang ingin menggeluti suatu profesi harus mempunyai pengetahuan dan keterampilan khusus untuk menjalankan profesinya.

Kunandar (2007: 46) menjelaskan bahwa profesi adalah suatu keahlian dan kewenangan dalam suatu jabatan yang mensyaratkan keahlian atau kompetensi khusus yang meliputi pengetahuan, sikap dan keterampilan yang diperoleh dari pendidikan akademis yang intensif. Hal ini berarti profesi hanya dapat dilaksanakan oleh seseorang yang telah menempuh pendidikan akademis sampai mendapat keahlian atau kompetensi yang diperlukan untuk menjalankan suatu profesi. Guru merupakan salah satu contoh profesi. Pendidikan keguruan yang intensif diperlukan agar seseorang dapat menjalankan profesinya sebagai seorang guru.

UU Nomor 14 Tahun 2005 tentang Guru dan Dosen menjelaskan yang dimaksud oleh profesional adalah pekerjaan atau kegiatan yang dilakukan oleh seseorang dan menjadi sumber penghasilannya yang memerlukan keahlian, kemahiran, atau standar mutu atau norma tertentu serta memerlukan pendidikan profesi. Penjelasan ini menunjukkan bahwa profesional menunjuk pada pekerjaan yang dilakukan oleh seorang untuk memenuhi kebutuhannya.

Profesionalisme merupakan suatu gambaran mengenai kondisi atau keadaan, derajat, kualitas, kemampuan dan penampilan seorang yang menjalankan suatu profesi tertentu. Profesionalisme tidak selalu menunjukkan hasil yang baik karena profesionalisme merupakan suatu gambaran atau ukuran. Profesionalisme bisa menunjukkan hasil yang baik dan buruk tergantung bagaimana penampilan orang yang dinilai.Modul pembelajaran merupakan satuan program belajar mengajar yang terkecil, yang dipelajari oleh siswa sendiri secara perseorangan atau diajarkan oleh siswa kepada dirinya sendiri. Guru merupakan seorang bertugas untuk memberikan bimbingan dan pengajaran kepada muridnya agar terjadi perubahan tingkah laku pada muridnya. Perubahan yang terjadi dapat berupa dari yang tidak bisa menjadi bisa, dari yang tidak tahu menjadi tahu, dari tidak baik menjadi baik dan sebagainya.

Kunandar (2007: 54) berpendapat bahwa guru merupakan pendidik profesional dengan tugas utama mengajar, mendidik, mengajar, membimbing, mengarahkan, melatih, menilai, dan mengevaluasi peserta didik pada semua jenjang pendidikan. Secara tidak langsung, dari definisi ini dapat dilihat bahwa guru merupakan pendidik yang memiliki kompetensi untuk 
mengajar dengan tujuan utamanya adalah mengubah siswa. Mengubah siswa di sini artinya mengubah siswa menjadi lebih baik dari sebelumnya,baik dari sisi pengetahuan, keterampilan maupun sikapnya. Salah satu contohnya adalah merubah siswa dari yang tidak tahu menjadi tahu, dari yang tidak bisa menjadi bisa, dari yang tidak terampil menjadi terampil, dari yang tidak baik menjadi baik dan sebagainya.

Guru adalah seorang yang memiliki kemampuan atau kompetensi mengelola pembelajaran yang bertugas untuk membimbing, mendidik, mengajar, mengarahkan, melatih dan mengevaluasi peserta didik. Tujuannya adalah agar terjadi perubahan pada diri peserta didik yang diajar. Perubahan yang dimaksud adalah perubahan menuju yang lebih baik.

Menurut Undang-Undang Republik Nomor 14 Tahun 2005 tentang Guru dan Dosen dijelaskan bahwa: "kompetensi adalah seperangkat pengetahuan, keterampilan, dan perilaku yang harus dimiliki, dihayati, dan dkuasai oleh guru atau dosen dalam melaksanakan tugas keprofesionalan. Terdapat 4 kompetensi yang harus dikuasai guru yang profesional. keempat kompetensi tersebut anatara lain.

Kompetensi profesional merupakan kemampuan dasar yang harus dimiliki oleh seorang guru. Kompetensi profesional meliputi kemampuan dalam menguasai pengetahuan secara luas dan mendalam yang memungkinkan pendidik untuk membimbing peserta didik dengan baik. Pengetahuan di sini tidak hanya sebatas materi yang akan diajarkan, tetapi juga pengetahuan mengenai dunia pendidikan.

Menurut PP No.74 Th. 2008 pasal 3 ayat 7 yang menyebutkan bahwa "Kompetensi Profesional merupakan kemampuan guru dalam menguasai pengetahuan bidang ilmu pengetahuan, teknologi, dan atau seni budaya yang diampunya yang sekurang-kurangnya meliputi penguasaan: materi pelajaran secara luas dan mendalam sesuai dengan standar ini program satuan pendidikan, mata pelajaran, dan/atau kelompok mata pelajaran yang akan diampu; dan konsep dan metode disiplin keilmuan, teknologi, atau seni yang relevan, yang secara konseptual menaungi atau koheren dengan program satuan pendidikan, mata pelajaran, dan/atau kelompok mata pelajaran yang akan diampu."

Kompetensi pedagogik merupakan kompetensi yang berkaitandengan kemampuan pengelolaan pembelajaran. Hal ini sesuaidengan Standar Nasional Pendidikan dalam penjelasan Pasal ayat (3) butir a dikemukakan bahwa kompetensi pedagogik adalahkemampuan mengelola pembelajaran peserta didik yang meliputipemahaman terhadap peserta didik, perancangan dan pelaksanaanpembelajaran, evaluasi hasil belajar, dan pengembangan pesertadidik untuk mengaktualisasikan berbagai potensi yang dimilikinyaMulyasa (2009: 75).

Menurut PP No 74 Tahun 2008 pasal 3 ayat 4 yang menyebutkan bahwa "Kompetensi Pedagogik merupakan kemampuan guru dalam pengelolaan pembelajaran peserta didik yang sekurang-kurangnya meliputi: pemahaman wawasan atau landasan kependidikan; pemahaman terhadap peserta didik; pengembangan kurikulum atau silabus; perancangan pembelajaran; pelaksanaan pembelajaran yang mendidik dan dialogis; pemanfaatan teknologi pembelajaran; evaluasi hasil belajar; dan pengembangan peserta didik untuk mengaktualisasikan berbagai potensi yang dimilikinya."

Kunandar (2007: 56) berpendapat bahwa kompetensi kepribadian adalah sikap guru yang berjiwa Pancasila yang mengutamakan budaya bangsa Indonesia. Pendapat tersebut menunjukkan bahwa guru dalam menjalankan profesinya sebagai Seorang pengajar tidak hanya harus memiliki pengetahuan yang bagus, tetapi juga harus memiliki kepribadaian yang baik, sehingga dapat menjadi contoh bagi peserta didik dalam membentuk pribadi peserta didik yang berakhlak mulia.

Menurut PP No.74 Tahun 2008 pasal 3 ayat 5 yang menyatakan bahwa "Kompetensi kepribadian sekurang- kuranngya mencakup kepribadian yang: beriman dan bertakwa; berakhlak mulia; arif dan bijaksana; demokratis; mantap; berwibawa; stabil; dewasa; jujur; sportif; menjadi teladan bagi peserta didik dan masyarakat; secara obyektif mengevaluasi kinerja sendiri; dan mengembangkan diri secara mandiri dan berkelanjutan."

Kompetensi sosial merupakan kemampuan guru dalam bergaul, berkomunikasi, dan berhubungan dengan peserta didik, sesama guru, orang tua/wali peserta didik serta masyarakat sekitar.Kunandar (2007: 56) yang menyebutkan bahwa kompetensi sosial adalah 
kemampuan yang berhubungan dengan bentuk partisipasi sosial seorang guru dalam kehidupan sehari-hari di masyarakat tempat ia bekerja, baik formal maupun informal.

PP No.74 Tahun 2008 pasal 3 ayat 6 yang menyatakan bahwa "kompetensi sosial merupakan kemampuan guru sebagai bagian dari masyarakat yang sekurang-kurangnya meliputi kompetensi untuk: berkomunikasi lisan, tulis, dan/atau isyarat secara santun; menggunakan teknologi komunikasi dan informasi secara fungsional; bergaul secara efektif dengan peserta didik, sesama pendidik, tenaga kependidikan, pimpinan satuan pendidikan, orang tua atau wali peserta didik; bergaul secara santun dengan masyarakat sekitar dengan mengindahkan norma serta sistem nilai yang berlaku; dan menerapkan prinsip persaudaraan sejati dan semangat kebersamaan."

Persepsi pada dasarnya adalah proses kognitif yang dialami seseorang dalam memahami informasi tentang dunia atau lingkungan melalui penglihatan, penghayatan, dan lain-lain. Persepsi setiap orang itu berbeda karena sebagai mahkluk individu setiap manusia memiliki pandangan yang berbeda sesuai dengan tingkat pengetahuan dan pemahamannnya.persepsi adalah pandangan atau kesan yang timbul pada seseorang terhadap suatu objek atau peristiwa setelah seseorang melalui proses pengamatan dengan panca inderanya yang kemudian disimpulkan berdasarkan informasi yang diterimanya.

\section{Metode}

Metode yang digunakan dalam penelitian ini adalah metode Kualitatif studi evaluasi. Dalam hal ini karena masalah yang diteliti merupakan fenomena secara luas dan mendalam sesuai dengan apa yang terjadi dan berkembang pada situasi sosial mengenai profesionalisme guru yang ditinjau dari persepsi siswa karena dapat diteliti secara kualitatif. Dimana masalah yang diteliti dapat diamati, dinilai, dan dianalisis secara langsung pada proses kegitaan pembelajaran guru mata pelajaran prakarya dan kewirausahaan karena segala sikap, prilaku, kinerja, cara mengajar, dan kedisiplinan guru akan dapat diteliti saat proses pembelajaran dan siswa merupakan subjek yang paling mengetahui dan sering berhubungan dengan guru. Sehingga model evaluasi yang digunakan adalah Formatif- Summatif Evaluation Model.

Evaluasi formatif secara prinsip merupakan evaluasi yang dilaksanakan ketika program sedang berlangsung. Tujuan evaluasi ini adalah mengetahui seberapa jauh program yang dirancang dapat dilaksanakan dan dapat mengetahui hambatan-hambatan didalam pelaksanaannya. Evaluasi sumatif dilaksanakan setelah program berakhir. Tujuan evaluasi sumatif ini adalah untuk mengukur ketercapaian program sebagai sarana yang berfungsi mengetahui hasil yang dicapai oleh objek penelitian.

Sumber data peneliti ini ditentukan secara purposive sampling (Sugiyono, 2015:299), yaitu dipilih berdasarkan pertimbangan dan tujuan tertentu, dalam rangka ketepatan dan kecukupan informasi yang dibutuhkan. Pertimbangan itu misalkan orang tersebut yang dianggap paling tahu tentang apa yang kita harapkan, atau mungkin dia sebagai penguasa sehingga akan memudahkan peneliti menjelajahi objek atau situasi sosial yang diteliti.

Data penelitian yang akan digunakan oleh peneliti didalam penelitian ini antara lain : 1) data hasil wawancara terhadap siswa; 2) data hasil telaah studi dokumen berupa RPP yang digunakan oleh guru untuk kelas XI MIA tahun ajaran 2017/2018; 3) data hasil observasi proses pembelajaran didalam kelas yang dilaksanakan oleh guru bersangkutan; 4) data hasil pengisian kuesioner yang dilakukan siswa selama mengikuti proses pembelajaran prakarya dan kewirausahaan. Data-data tersebut tentu berkaitan dengan bagaimana proses dan persiapan guru atau pendidik didalam melaksanakan pembelajaran prakarya dan kewirausahaan.

Menurut Sugiyono (2012:193 - 194) teknik atau metode pengumpulan data adalah caracara yang digunakan untuk menghimpun serangkaian data dengan prinsip-prinsip dan alatalat tertentu. Teknik pengumpulan data yang digunakan didalam penelitian ini adalah wawancara (interview), kuesioner (angket), studi dokumen, dan observasi partisipatif.

Menurut Sugiyono (2015:194) wawancara digunakan sebagai teknik pengumpulan data apabila penelii ingn melakukan studi pendahuluan untuk menemukan permasalahan yang harus diteliti, dan juga apabila peneliti ingin mengetahui hal-hal dari responden yang lebih mendalam dan jumlah respondenya sedikit/kecil. Wawancara terstruktur digunakan sebagai 
teknik pengumpulan data, bila peneliti atau pengumpul data telah mengetahui dengan pasti tentang informasi apa yang akan diperoleh. Oleh karena itu dalam melakukan wawancara, pengumpul data telah menyiapkan instrumen penelitian berupa pertanyaan-pertanyaan tertulis yang alternative jawabanya pun telah disiapkan.

Observasi partisitaif menurut Aziz (2012: 39) adalah suatu teknik penelitian yang bertujuan memperoleh suatu data melalui pengamatan langsung terhadap suatu objek pada periode tertentu. Jenis obsevasi partisipatif yang digunakan dalam penelitian ini adalah obsevasi partisipatif terbuka, dimana dalam mengumpulkan data, peneliti melakukan observasi partisipatif pada semua aktivitas sumber data, namun hanya beberapa kegiatan yang terkait dengan fokus penelitian. Selama obsevasi berlangsung, peneliti melakukan kegiatan pencatatan, perekaman, pendeskripsian dan penginterpretasian data yang berkaitan dengan fokus penelitian.

Menurut Sugioyo (2012: 198-199 ), Studi dokumen digunakan sebagai pelengkap dari data yang diperoleh dari metode wawancara mendalam dan observasi partisipatif. Data penelitian dari hasil wawancara dan observasi akan lebih dapat dipercaya, jika didukung oleh suatu dokumen tentang data tersebut. Didalam teknik studi dokumen, peneliti melakukan telaah atau pemeriksaan kesesuaian isi terhadap dokumen perencanaan pembelajaran yang telah dibuat atau dimiliki oleh narasumber dengan berpedoman pada Permendikbud 2016.

Pemberian angket digunakan sebagai data pelengkap dari data-data yang diperoleh dari instrumen wawancara, observasi dan dokumentasi selama menjalankan penelitian. Penelitian ini menggunakan instrument angket dengan model Close Ended Questionnaire dalam bentuk Close Ended Questionnaire Cheklist.

Adapun kriteria profesionalisme guru agar dapat dikatakan seorang guru yang profesioal diantarnya dilihat dari empat kompetensi guru yang harus dicapai berdasarkan PP No.74 Tahun 2008 dan Permendiknas No.16 Tahun 2007 antara lain.

Kompetensi Profesional, antara lain Menguasai materi, struktur, konsep, dan pola pikir keilmuan yang mendukung mata pelajaran yang diampu; Menguasai standar kompetensi dan kompetensi dasar mata pelajaran yang diampu; Mengembangkan materi pembelajaran yang diampu secara kreatif; Mengembangkan keprofesionalan secara berkelanjutan dengan melakukan tindakan reflektif; Memanfaatkan teknologi informasi dan komunikasi untuk mengembangkan diri.

Kompetensi Pedagogik, antara lain Menguasai karakteristik peserta didik dari aspek fisik, moral, spiritual, sosial, kultural, emosional, dan intelektual; Menguasai teori belajar dan prinsipprinsip pembelajaran yang mendidik; Mengembangkan kurikulum yang terkait dengan mata pelajaran yang diampu; Menyelenggarakan pembelajaran yang mendidik; Memanfaatkan teknologi informasi dan komunikasi untuk kepentingan pembelajaran; Memfasilitasi pengembangan potensi peserta didik untuk mengaktualisasikan berbagai potensi yang dimiliki; Berkomunikasi secara efektif, empatik, dan santun dengan peserta didik; Menyelenggarakan penilaian dan evaluasi proses dan hasil belajar; Melakukan tindakan reflektif untuk peningkatan kualitas pembelajaran.

Kompetensi Kepribadian, antara lain Bertindak sesuai dengan norma agama, hukum, sosial, dan kebudayaan nasional Indonesia; Menampilkan diri sebagai pribadi yang jujur, berahklak mulia, dan teladan bagi peserta didik dan masyarakat; Menampilkan diri sebagai pribadi yang mantap, stabil, dewasa, arif, dan berwibawa; Menunjukkan etos kerja, tanggung jawab yang tinggi, rasa bangga menjadi guru, dan rasa percaya diri

Kompetensi Sosial, antara lain Bersikap inklusif, bertindak objektif, serta tidak diskriminatif karena pertimbangan jenis kelamin, agama, ras, kondisi fisik, latar belakang keluarga, dan status sosial ekonomi; Berkomunikasi secara efektif, empatik, dan santun dengan sesame pendidik, tenaga kependidikan, orang tua, dan masyarakat; Beradaptasi di tempat bertugas di seluruh wilayah Republik Indonesia yang memiliki keragaman sosial budaya; Berkomunikasi dengan komunitas profesi sendiri dan profesi lain secara lisan dan tulisan atau bentuk lain.

Analisis data kualitatif adalah upaya yang dilakukan dengan jalan bekerja dengan data, mengorganisasikan data, memilah menjadi satuan yang dapat dikelola, mensintesiskannya, mencari dan menemukan pola, menemukan apa yang penting dan apa yang dipelajari, dan 
memutuskan apa yang dapat diceritakan kepada orang lain. Keberadaan data yang didapatkan oleh peneliti di lapangan mengharuskan adanya analisis data secara sistematis, supaya data yang didapatkan memadai, akurat, dan dapat mengungkap keadaan sebenarnya kondisi di lapangan.

Teknik analisis data menggunakan beberapa alur kegiatan, yaitu : 1) reduksi data, 2) penyajian data, 3) verifikasi data, 4) penarikan kesimpulan, sebagai suatu langkah yang saling terkait pada saat sebelum, selama dan sesudah pengumpulan data dalam bentuk sejajar untuk membangun wawasan umum (Miles dan Huberman, 1992:19).

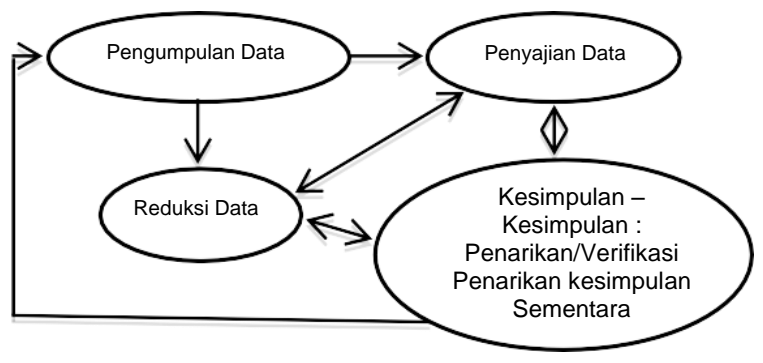

\section{Gambar 1. Komponen-Komponen Dalam Analisis Data : Model Interaktif}

Data yang diperoleh berupa kata-kata yang tersusun dalam kalimat yang harus dianalisis secara mendalam dan bersamaan kemudian dilakukan reduksi data melalui proses pemilihan dan pengkategorian data-data yang sesuai dengan fokus penelitian. Reduksi data bertujuan untuk menggolongkan, mengarahkan, menajamkan, membuang data yang tidak perlu, dan mengorganisasikan data dari hasil kuesioner, catatan pengamatan di lapangan dan dokumentasi berupa arsip dan foto-foto untuk kemudian dikaji dan disajikan dalam laporan penelitian.

\section{Hasil dan Pembahasan}

Kompetensi profesional dari aspek menguasai standar kompetensi dan kompetensi dasar mata pelajaran/bidang pengembangan yang diampu guru selalumenjelaskan tujuan pembelajaran dan standar kompetensi dan kompetensi dasar tersebut pada awal materi atau awal bab pada semester tersebut. Guru juga menguasai materi, struktur, konsep, dan pola pikir keilmuan yang mendukung mata pelajaran prakarya dan kewiraushaan yang diampu. Dalam mengembangkan materi pelajaran yang diampu secara kreatif guru menggunakan berbagai macam metode mengajar seperti diskusi kelompok, Tanya jawab, ceramah. Selain itu guru juga memanfaatkan teknologi informasi dan komunikasi untuk berkomunikasi dan mengembangkan diri dengan baik melalui selalu memanfaatan LCD proyektor dan laptop dalam mengajar. Sebagai bentuk mengembangkan keprofesionalan secara berkelanjutan dengan melakukan tindakan reflektif.

Guru selalu menyimpulkan hasil dari proses pembelajaran yang dilaksanakan diakhir pembelajaran. Sesuai dengan kriteria kompetensi profesional yang diisyaratkan PP No.74 Tahun 2008 dan Permendiknas No.16 Tahun 2007 dari semua kriteria, guru telah memenuhi semua indikator apa yang harus dicapai sebagai guru dalam kompetensi professional.

Hal tersebut didukung dengan hasil kuesioner yang diberikan kepada 70 siswa sebagai rensponden kuesioner sebagai sudut pandang dari penelitian mengenai profesionalisme guru, didapatkan nilai variabel rata-rata t-hitung sebesar 0.489 . Angka tersebut jauh lebih besar dari t-tabel pengujian product moment dengan jumlah rensponden 70 siswa sebesar 0.235 . Perbedaan tersebut menunjukan bahwa seluruh intrumen pada angket yang disebar dapat diuji kebenarannya dan sesuai dengan apa yang dialami oleh siswa. Pengujian reliabilitas pada penyebaran angket ini menggunakan pengujian alpha cronbach mendapatkan hasil perhitungan sebesar 0.717. Angka pngujian ini jauh lebih besar dari skala yang sudah ditentukan oleh Guilford yaitu $0.60<$ hasil $<0.80$. Hasil tersebut berada pada derajat reliabilitas tinggi karena hasil 0,717 lebih besar dari 0,60 dan lebih kecil dari 0,80. Sehingga hasil tersebut masuk dalam kategori tinggi. Dengan kata lain, respon terhadap kompetensi profesional guru 
mata pelajaran prakarya dan kewirausahaan menurut persepsi siswa adalah baik atau sudah sesuai dengan keadaan yang sebenarnya.

Didukung dengan hasil pengategorian kuesioner pada kriteria sangat baik. Hal tersebut sesuai dengan PP No.74 Th. 2008 pasal 3 ayat 7 tentang kompetensi profesional, kompetensi pedagogik indikator mengidentifikasi bekal ajar awal peserta didik, guru mempersiapkan siswa dengan cara menyuruh siswa membaca buku atau materi terlebih dahulu, ataupun mengingatkan kembali akan pelajaran sebelumnya. Dalam menentukan strategi pembelajaran berdasarkan karakteristik peserta didik dari masing masing siswa, dimana karakter siswa yang berbeda-beda menjadikan strategi pebelajaran yang digunakan yaitu secara umum sehingga semua siswa dapat memahami pembelajaran. Mencermati hasil analisis kuesioner penelitian, dapat diketahui bahwa guru yang mengajar mata pelajaran prakarya dan kewirausahaan memiliki kompetensi pedagogik yang sangat baik. Menurut PP No.74 Tahun 2008, guru memiliki pemahaman akan psikologi perkembangan anak, sehingga mengetahui dengan benar pendekatan yang tepat yang dilakukan pada anak didiknya. Guru selalu merancang dan melaksanakan evaluasi proses dari hasil belajar secara berkesinambungan dengan berbagi metode seperti ulangan, kuis, tes, dan tanya jawab secara langsung dengan memberikan poin atau reward. dimana guru mencantumkan tes tulis pada akhir pembelajaran. Sesuai dengan Permendikbud No 22 Tahun 2016 menyatakan bahwa "Evaluasi hasil pembelajaran dilakukan saat proses pembelajaran dan di akhir satuan pelajaran dengan menggunakan metode dan alat: tes lisan/perbuatan, dan tes tulis. Hasil evaluasi akhir diperoleh dari gabungan evaluasi proses dan evaluasi hasil pembelajaran".

Selain itu guru dalam memahami peserta didik dengan memanfaatkan prinsip-prinsip kepribadian dengan cara mengamati tingkah laku, sikap, dan perilaku siswa dalam mengikuti pembelajaran seperti halnya jika ada siswa yang menggangu kegiatan pembelajaran guru akan bersikap tegas dengan menegur dan menasehati siswa tersebut serta mencatatnya pada jurnal guru. Selain itu dalam pembelajaran prakarya dan kewirausahaan guru terkadang menata latar pembelajaran yang disesuaikan dengan metode pembelajaran. Hal tersebut sesuai dengan PP No 74 Tahun 2008 pasal 3 ayat 4 tentang kompetensi pedagogik

Terlepas dari hal tersebut ada beberapa indikator yang kurang sesuai atau belum terlaksana seperti perancangan pembelajaran dan pelaksanaan pembelajaran yang mendidik dimana guru dalam pembelajaran tidak selalu sesuai atau tidak berpedoman pada RPP. Hal tersebut kurang sesuai dengan Permendikbud No.22 Tahun 2016 yang menyatakan bahwa pelaksanaan pembelajaran merupakan implementasi dari RPP, meliputi kegiatan pendahuluan, inti dan penutup.

Secara keseluruan pada kompetensi pedagogik dapat dikatakan masih kurang karena dari semua kriteria pada kompetensi pedagogik, guru belum memenuhi satu kriteria yang diisyaratkan oleh PP No.74 Tahun 2008 dan Permendiknas No.16 Tahun 2007. Hal tersebut didukung dengan hasil kuesioner yang diberikan kepada 70 siswa sebagai rensponden kuesioner sebagai sudut pandang dari penelitian mengenai profesionalisme guru, didapatkan nilai variable rata-rata t-hitung sebesar 0.466 . Angka tersebut jauh lebih besar dari t-tabel pengujian product moment dengan jumlah rensponden 70 siswa sebesar 0.235 . Perbedaan tersebut menunjukan bahwa seluruh intrumen pada angket yang disebar dapat diuji kebenarannya dan sesuai dengan apa yang dialami oleh siswa. Pengujian reliabilitas pada penyebaran angket ini menggunakan pengujian alpha cronbach mendapatkan hasil perhitungan sebesar 0.635. Angka pngujian ini jauh lebih besar dari skala yang sudah ditentukan oleh Guilford yaitu $0.60<$ hasil $<0.80$. Hasil tersebut berada pada derajat reliabilitas tinggi karena hasil 0,717 lebih besar dari 0,60 dan lebih kecil dari 0,80. Sehingga hasil tersebut masuk dalam kategori tinggi. Dengan kata lain, respon terhadap kompetensi pedagogik guru mata pelajaran prakarya dan kewirausahaan menurut persepsi siswa adalah baik atau sudah sesuai dengan keadaan yang sebenarnya.

Kompetensi kepribadian dalam aspek guru memiliki perilaku yang disegani ditunjukan dari sikap dan perilaku guru dalam menangani siswa yang menganggu dalam pembelajaran. Dimana guru menegur dan memberikan beberapa pertanyaan terkait materi pelajaran pada siswa yang menganggu pelajaran. Selain itu dalam kompetensi kepribadian guru harus memiliki etos kerja yang tinggi sebagai guru dimana guru selalu terlihat bersemangat dalam 
mengajar, percaya diri, dan bangga menjadi guru. Dalam menampilkan tindakan yang didasarakan pada kemanfaatan peserta didik, guru selalu membantu siswa apabila siswa mendapat kesulitan dalam memahami materi dengan menjelaskan kembali materi yang disampaikan. Dalam bertindak sesuai dengan norma hukum dan sosial guru selalu datang tepat waktu dalam mengajar, dan dalam bersikap guru selalu sopan, santun, dan bisa bercanda kepada siswa. Sesuai dengan kriteria kompetensi kepribadian yang diisyaratkan PP No.74 Tahun 2008 dan Permendiknas No.16 Tahun 2007 dari semua kriteria, guru telah memenuhi semua indikator apa yang harus dicapai sebagai seorang guru dalam kompetensi kepribadian.

Hal tersebut didukung dengan hasil kuesioner yang diberikan kepada 70 siswa sebagai rensponden kuesioner sebagai sudut pandang dari penelitian mengenai profesionalisme guru, didapatkan nilai variable rata-rata t-hitung sebesar 0.584 . Angka tersebut jauh lebih besar dari t-tabel pengujian product moment dengan jumlah rensponden 70 siswa sebesar 0.235 . Perbedaan tersebut menunjukan bahwa seluruh intrumen pada angket yang disebar dapat diuji kebenarannya dan sesuai dengan apa yang dialami oleh siswa. Pengujian reliabilitas pada penyebaran angket ini menggunakan pengujian alpha cronbach mendapatkan hasil perhitungan sebesar 0.863. Angka pngujian ini jauh lebih besar dari skala yang sudah ditentukan oleh Guilford yaitu $0.80<$ hasil $<1.00$.

Hasil tersebut berada pada derajat reliabilitas sangat tinggi karena hasil 0,863 lebih besar dari 0,80 dan lebih kecil dari 1,00. Sehingga hasil tersebut masuk dalam kategori sangat tinggi. Dengan kata lain, respon terhadap kompetensi kepribadian guru mata pelajaran prakarya dan kewirausahaan menurut persepsi siswa adalah baik atau sudah sesuai dengan keadaan yang sebenarnya. Didukung dengan hasil pengkategorian kuesioner pada kriteria sangat baik. Hal ini sesuai dengan PP No.74 Tahun 2008 pasal 3 ayat 5 tentang Kompetensi kepribadian. Kompetensi sosial dalam aspek kompetensi sosial bertindak inklusif, bertindak objektif, serta tidak diskriminatif guru tidak pernah membeda-bedakan siswa dan selalu bersikap secara adil kepada semua siswa. Dalam berkomunikasi dengan sesama guru, tenaga kependidikan, orang tua, peserta didik, dan masyarakat guru berperan aktif misalkan pada kegiatan ulang tahun sekolah, dengan membantu siswa dalam latihan dan mengawasi. Selain itu guru selalu ramah dan satun pada siswa, baik didalam kelas maupun diluar kelas. Sesuai dengan kriteria kompetensi sosial yang diisyaratkan PP No.74 Tahun 2008 dan Permendiknas No.16 Tahun 2007 dari semua kriteria, guru telah memenuhi semua indikator apa yang harus dicapai sebagai seorang guru dalam kompetensi sosial.

Hal tersebut didukung dengan hasil kuesioner yang diberikan kepada 70 siswa sebagai rensponden kuesioner sebagai sudut pandang dari penelitian mengenai profesionalisme guru, didapatkan nilai variable rata-rata t-hitung sebesar 0.553 . Angka tersebut jauh lebih besar dari t-tabel pengujian product moment dengan jumlah rensponden 70 siswa sebesar 0.235.

Perbedaan tersebut menunjukan bahwa seluruh intrumen pada angket yang disebar dapat diuji kebenarannya dan sesuai dengan apa yang dialami oleh siswa. Pengujian reliabilitas pada penyebaran angket ini menggunakan pengujian alpha cronbach mendapatkan hasil perhitungan sebesar 0.688. Angka pngujian ini jauh lebih besar dari skala yang sudah ditentukan oleh Guilford yaitu $0.60<$ hasil $<0.80$. Hasil tersebut berada pada derajat reliabilitas tinggi karena hasil 0,688 lebih besar dari 0,60 dan lebih kecil dari 0,80. Sehingga hasil tersebut masuk dalam kategori tinggi. Dengan kata lain, respon terhadap kompetensi sosial guru mata pelajaran prakarya dan kewirausahaan menurut persepsi siswa adalah baik atau sudah sesuai dengan keadaan yang sebenarnya. Didukung dengan hasil pengkategorian kuesioner pada kriteria sangat baik.Hal ini sesuai dengan PP No.74 Tahun 2008 pasal 3 ayat 6 tentang kompetensi sosial Berdasarkan analisis data dan pembahasan dapat disimpulkan hal-hal antara lain: secara garis besar, profesionalisme guru mata pelajaran prakarya dan kewirausahaan yang ditinjau dari persepsi siswa masih kurang. Karena kompetensi pedagogik belum memenuhi semua kriteria yang disyaratkan. Kompetensi yang memenuhi kriteria hanya tiga kompetensi dari empat kompetensi yang disyaratkan oleh PP No.74 Tahun 2008 dan Permendiknas No.16 Tahun 2007. Yaitu kompetensi profesional, kompetensi kepribadian, dan kompetensi sosial, dimana dari kompetensi pedagogik guru belum memenuhi semua kriteria yang disyaratkan. Yaitu kriteria perancangan pembelajaran dan pelaksanaan pembelajaran 
yang mendidik dimana guru dalam pembelajaran tidak selalu sesuai atau tidak berpedoman pada RPP.

Hal tersebut kurang sesuai dengan Permendikbud No.22 Tahun 2016 yang menyatakan bahwa pelaksanaan pembelajaran merupakan implementasi dari RPP, meliputi kegiatan pendahuluan, inti dan penutup. Adapun beberapa saran yang dapat disampaikan oleh peneliti terkait profesionalisme guru mata pelajaran prakarya dan kewirausahaan yang telah dilakukan antara lain, Guru diharapkan dapat mempertahankan keprofesionalan dalam pembelajaran mata pelajaran prakarya dan kewirausahaan serta mengembangkan profesionalisme tersebut sebagai seorang pendidik agar menjadi guru yang lebih baik sesuai dengan perkembangan zaman, ilmu pengetahuan, dan teknologi; Guru diharapkan mampu melaksanakan pembelajaran sesuai dengan rancangan pelaksaaan pembelajaran yang telah dibuat dan sesuai dengan Permendikbud No.22 Tahun 2016; Selain itu guru diharapkan mampu menggunakan waktu dengan baik agar pelaksanaan pembelajaran yang terdiri dari tiga tahap, yaitu pendahuluan, kegiatan inti, dan penutup mendapat waktu yang ideal agar kelima langkahlangkah pendekatan saintifik bisa terlaksana secara optimal disertai dengan penilaianpenilaian yang seharusnya dilakukan dalam setiap pertemuan.

\section{Daftar Pustaka}

Arikunto, Suharsimi., dan Safruddin, Cepi. 2009. Evaluasi Program Pendidikan (Edisi 2). Jakarta: PT. Bumi Aksara.

Fathurrohman, Pupuh \& Sutikno Sobry. 2011. Strategi Belajar Mengajar: Strategi Mewujudkan Pembelajaran Bermakna Melalui Penanaman Konsep Umum \& Islami. Bandung: Refika Aditama

Firdaus, M. Aziz. 2012. Metode Penelitian. Tanggerang Selatan: Jelajah Nusa.

Kementerian Pendidikan dan Kebudayaan. 2007. Peraturan Menteri Pendidikan danKebudayaan Nomor 16 Tahun 2007 tentang Standar Kualifikasi Akademik \& Kompetensi Guru. Tersedia pada: (http://luk.staff.ugm.ac.id/atur/bsnp/ Permendiknas16-2007KompetensiGuru.pdf). Diunduh pada tanggal 22 Desember 2016

Kementerian Pendidikan dan Kebudayaan. 2016. Peraturan Menteri Pendidikan dan Kebudayaan Nomor 22 Tahun 2016 tentang Standar Proses Pendidikan Dasar dan Menengah. Tersedia pada: (http://bsnpindonesia.org/wpcontent/uploads/2009/06/ Permendikbud_Tahun2016_Nomor02 2_Lampiran.pdf). Diunduh pada tanggal 24 September 2017.

Kunandar. 2007. Guru Profesional: Implementasi Kurikulum Tingkat SatuanPendidikan (KTSP) dan Sukses dalam Sertifikasi Guru. Jakarta: RajawaliPers.

Miles, B.M \& Huberman, M.A.1992. Analisis Data Kualitatif. Penerjemah: Rohidi, R.T. Universitas Indonesia. Jakarta.

Mulyasa. 2009. Standar Kompetensi dan Setifikasi guru. Bandung: Remaja Rosda Karya Peraturan Pemerintah Nomor 19 Tahun 2005 tentang Standar Nasional Pendidikan. Tersedia pada: (http://telkomuniversity.ac.id/images/uploads/PP_No._19_ Tahun_2005.pdf). Diunduh pada tanggal 22 Desember 2016.

Peraturan Pemerintah Nomor 74 Tahun 2008 tentang Guru. Tersedia pada: (http://unnes.ac.id/wp-content/uploads/PP_74_Tahun_2008.pdf). Diunduh pada tanggal 24 September 2017.

Sugiyono. 2012. Statistika Untuk Penelitian. Bandung: Alfabeta. 
Sugiyono.2015. Metode Penelitian Pendidikan (Pendekatan Kuantitatif, Kualitatif, dan R\&D). Bandung: Alfabeta.

Zahroh, Aminatul. 2015. Membangun Kualitas Pembelajaran melalui Dimensi Profesionalisme Guru.Bandung: CV Yrama Widya. 